\title{
HOW MUCH WILL I EARN? EXPECTATIONS VERSUS REALITY
}

\author{
Jana Šimsová, Alice Reissová
}

\section{Introduction}

Work is a very important part of human life. Young people think about their future employment on the labour market and choose their future jobs according to many criteria. Sometimes they choose according to the field they are interested in, in other cases their choice could be influenced by their parents. Motivation for the job choice can be different, but very often the aspect of salary plays an important role, i.e. the salary, which one could expect in a given profession.

We were primarily interested in the issue to what extent the expectations of young people are realistic. Up until now most studies have dealt predominantly with returns on investments into education. For example Walker and Zhu (2011) examined estimations in the light of the impact, which university education can have on the future level of salaries according to the studied field in the UK. Delaney, Harmon and Remond (2011) were examining the interaction between the socio-economic status and the level of education and the expectations for future returns from university education in Ireland. They came to the conclusion that there are significant differences in expectations with respect to differing socio-economic cohorts. Students with low socio-economic status expect discrimination upon their entry into the labour market and that is why the returns on investments into education could be underestimated. The issue of returns on investments into education has been dealt with by a number of authors throughout the entire world, e.g. Menon compares the diversity in the perceived rate of returns in Cyprus (Menon, 1997), and in China, vast research was carried out by Hartog, Ding and Liao (2014), who questioned university students in Beijing. In Europe, this issue has been dealt with by Marsikova and Anchor (2006). They stress in their work that a significant role can also be played by differing systems of university education. They compare the Czech Republic, where students can study free of charge at public colleges and universities or at private tertiary schools, where they pay school fees. On the other hand, there are relatively few private universities and colleges in the UK, but school fees are paid in public tertiary schools as well. In their conclusions, the authors come to the finding that the expectations for profit and the rate of returns differ according to both gender and country. Nevertheless students are rather optimistic and perceive a higher education as an advantageous investment. These findings are in accordance with most undertaken studies.

The issue of returns on investments is closely related to the aspect of salary expectations on the part of students and the level of reality with respect to these expectations. Also this topic has been elaborated in a number of studies, but predominantly in the USA.

The level of starting salary, which students expect, has been examined by Maddocks and Poole (2009). They compared the reactions of students to the average data, stated by PayScale. The expectations of students (both men and women) were higher than the real level of wages, whereby men expected higher salaries than women. Similar results were found by Heckert and Wallis (1998), but lower expectations were stated by women possessing only a bachelor level of education. On the other hand, women, who want to continue their studies, do have similar expectations to men.

Betts in his research posed questions to some students from the University of California in San Diego regarding the estimate salaries for different working positions. The difference between their estimates and reality fluctuated around $20 \%$. The estimates on the part of senior students were more realistic than those 
of freshmen. The family context and the level of parents' salaries also influenced the reality of the expectations (Betts, 1996). The fact that the expectations evolve during the course of students' studies is referred to also in other studies. The conclusion that expectations of senior students are more realistic is presented by Botelho and Pinto (2004), who carried out research among the students of the College of Business and Economics, at the University of Minho, Portugal.

Some studies, on the contrary, state that students usually underestimate their future salaries. For example Carvajal found that such underestimation may be closely related to ethnicity. In his study, the respondents were students at the Florida International University in Miami. He came to the conclusion that Hispanic students expect a lower salary than "the others". Another interesting finding was that in the students' eyes, the factor of age was overestimated. (Carvajal et al, 2000).

Another study, emanating from the USA, was presented by Dominitz and Manski (1996). In the framework of their research, students should have stated their expectations for salaries, which they would be able to earn, after finishing different levels of education. Although the authors themselves point out that their research sample of respondents was small and somewhat idiosyncratic, in their conclusions they state that students were well informed about the real wages and that they believed that investments into education pay off. An interesting finding was also the fact that students have a tendency to overestimate the current level of salary imbalance in the American society.

Similar conclusions could be found in Europe, in Webbink and Hartog work, who examined the responses on the part of Dutch students. They state that especially the students of social sciences, economics, health studies, agriculture and technical fields have very realistic estimates. According to their conclusions, students of foreign languages overestimate their future salaries and students from higher income families are also more optimistic. (Webbink \& Hartog, 2004)

Jerrim points out that even if the issues of salary expectations have a significant value for the theory of human capital and public policy, they are nonetheless paid relatively small attention. In his study, which he carried out among tertiary students in the UK, he states that students overestimate their starting salaries by roughly $15 \%$. This discrepancy does not always have to be detrimental. It may lead to a higher effort in the finding of a job. The expectations of a higher salary do not necessarily have to mean that students have inadequate information about the real situation on the labour market. It may be related to an inaccurate estimate of the employment position, for which they will be accepted. (Jerrim, 2011)

The absence of empirical studies in the area of expected incomes is also pointed out by Brunello. $\mathrm{He}$ carried out the first major supranational research regarding salary expectations in European tertiary schools among students of business and management. The research was carried out in several European countries. A sufficiently adequate research sample was achieved in Italy, Germany, Austria, Switzerland and Portugal; whereas in other countries the samples were smaller. They found that the level of the expected salary is in correlation with gender, age and seniority. Women expect substantially lower salaries and worse working conditions than men. An important factor is also that of family background; this was shown to play an important role. Another interesting finding was that students, studying at tertiary schools with demanding entrance exams, have higher expectations than their colleagues from private schools. (Brunello, Lucifora, \& WinterEbmer, 2004)

The databases of scientific articles present only a small amount of information regarding the salary expectations of those students from Middle and Eastern Europe. A comparative study of salary expectations among Swiss and US students has been carried out by Wolter. It is obvious from his conclusions that the high imbalance in the USA and high homogeneity in Switzerland have been overestimated by students. For their future, American students expect a higher growth in wages, whereas Swiss students are more conservative. (Wolter, 2000)

We could find some data from Middle and Eastern Europe in supranational studies, which have been carried out by renowned consulting companies. For example, international research with regard to students and graduates "First steps on labour market" has examined the differences between the average gross salary and that level of salary expected by students. 
The most significant divergence was found in Poland (expected salary is 492 Euros higher), then comes Slovakia (394 €), and in the Czech Republic the difference is $224 €$. The smallest differences were in Latvia $(275 €)$ and Lithuania (218 €). (Deloitte, 2011)

The German institution Trendence, which specializes in employer branding, personal marketing and recruiting, carries out yearly different investigations among pupils, students and graduates from the entire world. In the year 2014, they carried out research labelled "Graduate Barometre", in which 11,500 graduates participated. The results show that Czech graduates are more modest than their counterparts from the neighbouring countries from the eastern bloc (Slovakia, Hungary, Bulgaria). The average expectations are around $30,000 \mathrm{CZK}(1,100 €)$ per month. (Czech graduates "modest" regarding starting salaries, 2014). This is a higher sum than the average salary in the country. And we think that this is also higher than employers are willing to offer most graduates. That is why we will deal not only with the expectations of graduates but we will also compare them to the real offer on the part of their future employers.

The above stated facts prove that the issue of expected salaries on the part of students is important not only for the development of human capital and public policies (Jerrim, 2011), but also with regard to real demand on the part of future employers, which is reflected by commercial consulting companies, such as Deloitte or the German company Trendence.

\section{Methodology}

\subsection{Formulation of the Aim and Research Questions}

The main aim of our work was to verify whether the grade and branch of studies have influence on the expected level of salaries and to what extent the expectations of students are realistic in relation to the real offer of employers. We have adapted this broader aim into individual research questions. These studies undertaken have suggested that the level of education may be an important factor (Dominitz \& Manski, 1996; Delaney, Harmon, \& Remond, 2011; Heckert \& Wallis, 1998; and others). That is why we have examined whether there are differences in salary expectations with regard to the bachelor and master level of students. We suppose that students from the master level will have higher expectations that those from the lower, i.e. bachelor level.

Another factor, which may influence the expected level of the salary, may be the field studied (Webbink \& Hartog, 2004; Ettedge \& Nunamaker, 1993). The second research question thus concentrated on the finding whether there are differences in salary expectations in students from varying study programmes. We selected the programme of corporate economics and management and social work. We suppose that there is a certain impact with regard to the field studied and not only in the case of the starting salary, but also with regard to advancements during the course of employment.

Most studies, which deal with salary expectations on the part of students, work on one hand with primary data and question students and compare the responses to the secondary data (e.g. the average gross salary in a country or for an individual profession, panel research in households and so on.) The exceptionality of our work is in the fact that we compare primary data, derived from students to those primary data derived from individual potential employers. And that is why we have chosen two completely different study programmes (economics and social work) and thus we were forced to create two completely different sets of employers (firms and organisations).

The third research question, which we pose, is whether there are significant differences in gross starting salaries, which employers are able to offer graduates. We suppose that organisations will offer lower starting salaries than firms. The fourth research question is related to the following level of real growth in salaries. We also suppose that firms will offer a faster growth than organisations. The last research question is from our point of view the most interesting. We are interested in the direct confrontation between the real offers of employers and the students' expectations. We suppose that students of both study programmes will be more optimistic, i.e. their expectations for both starting salaries and salary advancements will be higher than those salaries offered by employers.

\subsection{Sample Description and Data Collection}

To be able to answer the formulated research questions, we had to create four representative samples. Two samples are formed by students 
(economic field and social work) and two samples are created by potential employers (firms and organisations). For economics students, a representative sample was a selected group of potential employers from the area of business i.e. profit sector. For social work students, it was a group of organisations, i.e. non-profit sector.

Data collection was carried out in the form of personal inquiries during two periods, in April and September 2013. In each period both students and potential employers were questioned. Both groups were asked the same questions. Students were asked about their expectations for the level of their gross starting salary, their gross salary after a year of employment and after three years from the beginning of their employment. Employers were asked about which gross starting salaries they pay to graduates of the given studies, after one year and three years after starting the job. The level of the gross salary was in all those questioned categorized into six groups. They are less than 15,000 CZK; 15,000-19,999 CZK; 20,000-24,999 CZK; 25,000-29,999 CZK; 30,000-49,999 CZK and 50,000 CZK and more.

In April 2013, data collection was carried out among students studying economics at the Faculty of Social and Economic Studies at the Jan Evangelista Purkyně University in Ústí nad Labem and among the firms located within the area of the Ústí region. The sample was created on the basis of quota selection. Quota characteristics were the size of the firm according to the number of employees and the main area of activity (industry, trade, services, construction, and agriculture). On the whole, 329 students and 187 firms were questioned. Because we were interested in the expectations of students concerning their future jobs, only the second and third year students of bachelor and master levels were included in the sample. First year students were not included. We excluded them in accordance with the conclusion of the study, which found out that they do not have realistic expectations about their future jobs and this fact could distort the results (Botelho \& Pinto, 2004). Examining the results of questionnaires, 20 questionnaires filled out by students were excluded and 38 questionnaires filled out by firms were excluded as well. The reason for that was an incomplete questionnaire or the lack of positions for the graduates.
In September, a questionnaire research among students of social policy and social work at the Faculty of Social and Economic Studies at the Jan Evalista Purkyně in Ústí nad Labem was carried out and also among organisations working in social areas and employing social work graduates within the Ústí region. Once again, only the second and third year students were included in the sample. After excluding incorrectly filled out questionnaires, the research sample of students was comprised of 81 units and the research sample of employers of 135 organisations.

The data were processed and evaluated by means of MS Excel and STATISTICA. $X^{2}$ test for independence, homogeneity test, odds ratio and logarithmic-linear models were used as statistical methods.

\section{Results}

The results are presented in three subchapters. In the first part, expectations of students were analysed, and in the second an analysis of the employers' offer was carried out. In the third part, students' expectations and the real situation of employers were compared.

\subsection{Students' Expectation}

We will concentrate on the students of economics first. The selected sample was created by 309 students. Out of these, 160 students studied bachelor degree and 149 studied master degree.

Table 1 shows the absolute and relative frequencies of their responses. They were their expectations for their gross starting salary, gross salary after one year and after three years. Looking at the table, we can see that expectations of bachelor and master degree students do not differ very much. Modal categories are the same for those two groups. $41 \%$ of bachelors and $46 \%$ of masters expect their gross starting salary to be in the range between 15,000 and 19,999 CZK. The gross starting salary of more than 50,000 CZK was not expected by any of the students. A similar situation is in the case of the expected salary level after one year. The modal category is the same for both groups, and in comparison with the starting salary it rose into 20,000-24,999 category, which is expected by $39 \%$ of bachelor students and $41 \%$ of master students. We do not find big differences even in their expectations of the gross salary after three years; however the 
bachelor students are a little more optimistic. The modal category is the same for both groups again and it has shifted to the range 25,000 29,999 . The lowest category was not selected by any of those questioned.

We were interested in whether the response to all three questions is influenced by the level of respondents' studies. The $x^{2}$ test for independence was carried out. In the gross starting salary, the p-value is 0.178989 .
In case of the gross salary after one year, it is $p=0.564898$ and after three years it is $p=0.359074$. All $p$-values are lower than $5 \%$. The test thus did not confirm that the level of expectations of the salary is influenced by the type of students' studies.

Our first prerequisite that students of master level will have higher expectations than their counterparts from master level cannot therefore be confirmed.

\begin{tabular}{|c|c|c|c|c|c|c|c|c|}
\hline \multirow{2}{*}{\multicolumn{3}{|c|}{$\begin{array}{c}\text { Tab. 1: } \begin{array}{l}\text { Absolute and re } \\
\text { students of eco }\end{array} \\
\text { Expected salary in CZK }\end{array}$}} & \multirow{2}{*}{$\begin{array}{c}\text { Less than } \\
15,000\end{array}$} & \multirow{2}{*}{$\begin{array}{c}15,000- \\
19,999\end{array}$} & \multirow{2}{*}{$\begin{array}{c}20,000- \\
24,999\end{array}$} & \multirow{2}{*}{$\begin{array}{c}25,000- \\
29,999\end{array}$} & \multirow{2}{*}{$\begin{array}{c}30,000- \\
49,999\end{array}$} & \multirow{2}{*}{$\begin{array}{c}50,000 \\
\text { and more }\end{array}$} \\
\hline & & & & & & & & \\
\hline \multirow{4}{*}{$\begin{array}{l}\text { Expected } \\
\text { gross starting } \\
\text { salary }\end{array}$} & \multirow{2}{*}{ Bachelor } & $\mathrm{n}_{\mathrm{i}}$ & 13 & 65 & 59 & 22 & 1 & 0 \\
\hline & & $f_{i}$ & 0.08 & 0.41 & 0.37 & 0.14 & 0.01 & 0 \\
\hline & \multirow{2}{*}{ Master } & $\mathrm{n}_{\mathrm{i}}$ & 11 & 68 & 50 & 14 & 5 & 1 \\
\hline & & $f_{i}$ & 0.07 & 0.46 & 0.33 & 0.09 & 0.03 & 0.01 \\
\hline \multirow{4}{*}{$\begin{array}{l}\text { Expected } \\
\text { gross salary } \\
\text { after one year }\end{array}$} & \multirow{2}{*}{ Bachelor } & $\mathrm{n}_{\mathrm{i}}$ & 1 & 28 & 63 & 49 & 19 & 0 \\
\hline & & $f_{i}$ & 0.01 & 0.18 & 0.39 & 0.31 & 0.12 & 0 \\
\hline & \multirow{2}{*}{ Master } & $\mathrm{n}_{\mathrm{i}}$ & 2 & 32 & 60 & 43 & 10 & 2 \\
\hline & & $f_{i}$ & 0.01 & 0.21 & 0.41 & 0.29 & 0.07 & 0.01 \\
\hline \multirow{4}{*}{$\begin{array}{l}\text { Expected } \\
\text { gross salary } \\
\text { after three } \\
\text { years }\end{array}$} & \multirow{2}{*}{ Bachelor } & $\mathrm{n}_{\mathrm{i}}$ & 0 & 2 & 29 & 61 & 56 & 12 \\
\hline & & $f_{i}$ & 0 & 0.01 & 0.18 & 0.38 & 0.35 & 0.08 \\
\hline & \multirow{2}{*}{ Master } & $\mathrm{n}_{\mathrm{i}}$ & 0 & 7 & 36 & 52 & 43 & 11 \\
\hline & & $f_{i}$ & 0 & 0.05 & 0.24 & 0.35 & 0.29 & 0.07 \\
\hline
\end{tabular}

Note: $n_{i}$ means absolute frequency; $f_{i}$ means relative frequency.

The same questions were asked to students of bachelor programme: Social policy and social work. 81 students responded on the whole. The results are shown in table 2.

In table 2, we can find that the questioned students of social work were more modest than their counterpart colleagues studying economics. We compare now just the bachelor degree students. In the gross starting salary, the modal category is the same, gross starting salary between 15 and 20,000 is expected by $41 \%$ of economics students and $52 \%$ of social work students. In the case of the salary after one year, the situation is similar. Most questioned students from both groups expect a salary between 20-25,000 CZK. A difference appears in the case of gross salary after three years of employment. $61 \%$ of the questioned students of economics expected 25-30,000 CZK, whereas most students of social work (30\%) expect the salary of $20-25,000$ CZK. We were interested in whether the differences between those two groups are statistically significant. The test of homogeneity was carried out. In the case of gross starting salary p-value is $1.789498^{*} 10^{-5}$, in the case of salary after one year it is $1.11846^{*} 10^{-7}$, in the case of salary after three years it is $1.15569^{*} 10^{-11}$.

In all three cases the p-value was lower than the common levels of significance and that is why we reject the homogeneity between the groups. The test proved that students' expectations in the case of starting salary, the salary after one year and after three years of 

students of social policy and social work

\begin{tabular}{|c|c|c|c|c|c|c|c|}
\hline \multicolumn{2}{|c|}{ Expected salary in CZK } & \multirow{2}{*}{$\begin{array}{c}\text { Less than } \\
15,000\end{array}$} & \multirow{2}{*}{$\begin{array}{c}15,000- \\
19,999\end{array}$} & \multirow{2}{*}{$\begin{array}{c}20,000- \\
24,999\end{array}$} & \multirow{2}{*}{$\begin{array}{c}25,000- \\
29,999\end{array}$} & \multirow{2}{*}{$\begin{array}{c}30,000- \\
49,999\end{array}$} & \multirow{2}{*}{$\begin{array}{c}50,000 \\
\text { and more }\end{array}$} \\
\hline & & & & & & & \\
\hline \multirow{2}{*}{$\begin{array}{l}\text { Expected gross } \\
\text { starting salary }\end{array}$} & $n_{i}$ & 21 & 42 & 14 & 4 & 0 & 0 \\
\hline & $f_{i}$ & 0.26 & 0.52 & 0.17 & 0.05 & 0 & 0 \\
\hline \multirow{2}{*}{$\begin{array}{l}\text { Expected gross } \\
\text { salary after one } \\
\text { year }\end{array}$} & $n_{i}$ & 12 & 27 & 29 & 10 & 3 & 0 \\
\hline & $f_{i}$ & 0.15 & 0.33 & 0.36 & 0.12 & 0.04 & 0 \\
\hline \multirow{2}{*}{$\begin{array}{l}\text { Expected gross } \\
\text { salary after three } \\
\text { years }\end{array}$} & $n_{i}$ & 3 & 17 & 30 & 20 & 8 & 3 \\
\hline & $f_{i}$ & 0.04 & 0.21 & 0.37 & 0.25 & 0.1 & 0.04 \\
\hline
\end{tabular}

Note: $n_{i}$ means absolute frequency; $f_{i}$ means relative frequency.

employment are influenced by the fact, as to whether they study economics or social work.

The second research question, whether there are differences among expectations of students of different study programmes, was confirmed. We can thus say that the type of study programme is one of the important factors influencing the level of expected salaries.

We were further interested to determine the rate of advancement expectations of the students within the first three years from starting the career. Six salary categories were assigned increasing ordinal numbers. The expectations for the salary advancements for each respondent were acquired by deducing selected ordinal numbers of categories. We distinguished three types of salary advancements, zero growth, the growth by one category and the growth by two or more categories. We introduced marking $A$, $\mathrm{B}, \mathrm{C}$ to make it simple.

- A - expected growth in salaries within the first year.

- B - expected growth in salaries within the following two years ( $2^{\text {nd }}$ and $3^{\text {rd }}$ year).

- C - expected growth in salaries within the three years from the beginning.

The situation of the expected salary advancement in cases $A, B, C$ for students of economics and social work is shown in figure 1.

Figure 1 shows that after one year of employment, the salary growth by more than two categories is not expected by any student of social work. In all considered changes in salary levels, the students of economics are more optimistic than their counterparts from social work. During the first three years, all students of economics expect advancements in salary by at least one category. Most of them (precisely $58 \%$ ) expect the growth by at least one considered income category. On the contrary, there are some students of social work (more than 8\%), who do not expect any salary advancement during the first three years of their employment.

For confirming the statistical significance of the observed deviations, the test of homogeneity for both groups was employed. In the case of change between the gross starting salary and gross salary after one year the p-value was 0.00745 , in the case of change after one year and after three years, it was 0.01135 and in case of change between gross starting salary and gross salary after three years it was $4.07533^{*} 10^{-6}$.

All $p$-values are lower than $5 \%$. On the level of significance of $5 \%$, we reject the homogeneity of the division of both students' groups. It means that differencies in advancement expectations significantly differ in all observed periods.

We further grouped the values stated in tables 1 and 2 in such a way so that we got two salary categories. The first salary category is the gross salary of up to 19,999 CZK, the second is the gross salary of 20,000 CZK and higher. In other words, we added up the first two values in columns to reach the first data and the remaining values to reach the second data. This way, an association table was created. The salary categories will now be lower (till 19,999 CZK) and higher (20,000 CZK and more) of the gross payment. Firstly, we 


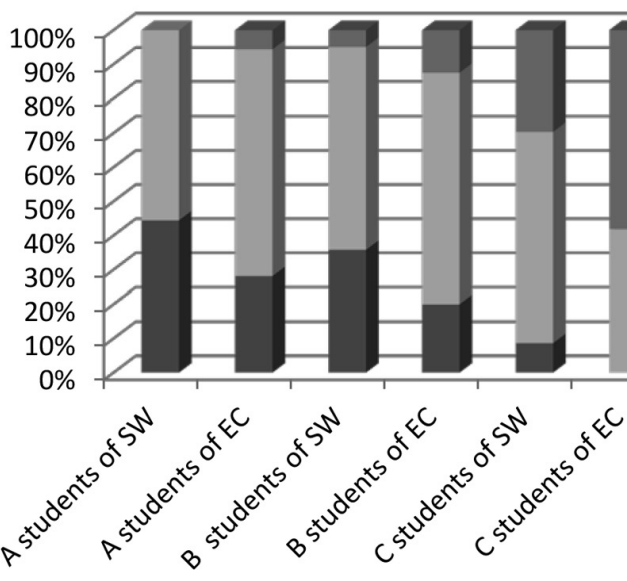

growth of salaries by two and more categories

growth of salaries by one category

zero growth of salaries will calculate ratios - higher gross salary $\left(2^{\text {nd }}\right.$ category): lower gross salary ( $1^{\text {st }}$ category). At first we will count these ratios for both examined groups of students. These ratios are called odds. This way we can express that in the case of the gross starting salary the students of economics estimate their odds for gross salaries in a higher category 82:78. Among students of social work, these odds are 18:63. Subsequently, we will calculate the quotient of these odds. This way we found, which group of students expects a higher chance for a higher salary. And this convenience can be quantified.

These odds ratios for expected gross salaries of students from the economics and social work fields are presented in table 3 . In this table, we can see the odds and odds ratios for acquiring the expected gross salary in a higher category by both groups of students. The graduates of economics expect 3.68 times greater odds for their higher starting salaries than those graduates from social work. In the case of the salary after one year of employment, these students see their odds for acquiring the salary of over 20,000 CZK 4.18 times higher than those students from social work. And in the case of the gross salary after three years of employment, the students of economics expect these odds as even 25.9 times higher than those students from social work.

These odds ratios were calculated from empirical data that is why they are empirical odds ratios. They are estimates of the theoretical odds ratios. Provided that the theoretical odds ratios equal zero, both groups see their odds the same way. An estimate of odds ratios could be acquired from a logarithmic-linear model, from which we also get the intervals of the reliability of these odds ratios. From table 3 , it is obvious that in all three examined questions, the value 1 is outside the $95 \%$ interval of reliability and that is why the stated odds ratios are statistically important.

\subsection{The Real Situation among Employers}

The same questions were posed both to students and their potential employers. The employers of economics graduates are generally referred to as firms and the employers of social work graduates will be generally referred to as organisations.

From the responses of employers of economics and social work graduates, we attained information as to which real wages they could offer to their employees. We were enquiring about the level of the gross starting salary, the salary after one year and after 


\begin{tabular}{|c|c|c|c|c|c|}
\hline & \multicolumn{3}{|c|}{ Odds for higher offered salaries } & \multicolumn{2}{|c|}{ Interval of reliability } \\
\hline Question & & Odds & Odds ratio & $2.50 \%$ & $97.50 \%$ \\
\hline \multirow{2}{*}{$\begin{array}{l}\text { Expected gross starting } \\
\text { salary }\end{array}$} & Students of economics & 1.05 & \multirow{2}{*}{3.68} & \multirow{2}{*}{1.97} & \multirow{2}{*}{6.13} \\
\hline & Students of social work & 0.29 & & & \\
\hline \multirow{2}{*}{$\begin{array}{l}\text { Expected gross salary after } \\
\text { one year }\end{array}$} & Students of economics & 4.52 & \multirow{2}{*}{4.19} & \multirow{2}{*}{2.33} & \multirow{2}{*}{7.66} \\
\hline & Students of social work & 1.08 & & & \\
\hline \multirow{2}{*}{$\begin{array}{l}\text { Expected gross salary after } \\
\text { three years }\end{array}$} & Students of economics & 79.00 & \multirow{2}{*}{25.9} & \multirow{2}{*}{7.27} & \multirow{2}{*}{165.34} \\
\hline & Students of social work & 3.05 & & & \\
\hline
\end{tabular}

three years of employment. Table 4 shows the absolute and relative frequencies of the individual responses to these three questions. From the table we can see that already in the gross starting salary, the situation is different. Whereas $54 \%$ of questioned organisations offer the graduates a gross salary of up to $15,000 \mathrm{CZK}, 48 \%$ of questioned firms offer the graduates a gross salary in the range between 15 and 20,000 CZK. Even in the salaries after one year of employment the difference is visible. All questioned organisations offer a maximum salary $25,000 \mathrm{CZK}$. And out of these, $62 \%$ offer salaries in the second category, i.e. between 15 and $20,000 \mathrm{CZK}$. The most frequented category among the questioned firms is between 20 and 25,000 CZK (42\%). A difference can also be seen in the salaries after three years from the beginning of employment. Whereas none of the questioned organisations offers a salary of more than 30,000 CZK, among those questioned firms $19 \%$ offer salaries from 30 to 50,000 CZK and $2 \%$ offer even a salary in the category 50,000 and higher.

\section{Tab. 4: Absolute and relative frequencies of the gross salaries offered by employers}

\begin{tabular}{|c|c|c|c|c|c|c|c|c|}
\hline \multicolumn{3}{|c|}{ Offered salary in CZK } & \multirow{2}{*}{$\begin{array}{c}\text { Less than } \\
15,000\end{array}$} & \multirow{2}{*}{$\begin{array}{c}15,000- \\
19,999\end{array}$} & \multirow{2}{*}{$\begin{array}{c}20,000- \\
24,999\end{array}$} & \multirow{2}{*}{$\begin{array}{c}25,000- \\
29,999\end{array}$} & \multirow{2}{*}{$\begin{array}{c}30,000- \\
49,999\end{array}$} & \multirow{2}{*}{$\begin{array}{c}50,000 \\
\text { and more }\end{array}$} \\
\hline & Questioned & & & & & & & \\
\hline \multirow{4}{*}{$\begin{array}{l}\text { Offered } \\
\text { gross starting } \\
\text { salary }\end{array}$} & \multirow{2}{*}{ Firms } & $n_{i}$ & 18 & 71 & 53 & 7 & 0 & 0 \\
\hline & & $f_{i}$ & 0.12 & 0.48 & 0.36 & 0.05 & 0 & 0 \\
\hline & \multirow{2}{*}{ Organisations } & $n_{i}$ & 73 & 57 & 5 & 0 & 0 & 0 \\
\hline & & $f_{i}$ & 0.54 & 0.42 & 0.04 & 0 & 0 & 0 \\
\hline \multirow{4}{*}{$\begin{array}{l}\text { Offered gross } \\
\text { salary after } \\
\text { one year }\end{array}$} & \multirow{2}{*}{ Firms } & $n_{i}$ & 6 & 39 & 63 & 37 & 4 & 0 \\
\hline & & $f_{i}$ & 0.04 & 0.26 & 0.42 & 0.25 & 0.03 & 0 \\
\hline & \multirow{2}{*}{ Organisations } & $\mathrm{n}_{\mathrm{i}}$ & 38 & 84 & 13 & 0 & 0 & 0 \\
\hline & & $f_{i}$ & 0.28 & 0.62 & 0.1 & 0 & 0 & 0 \\
\hline \multirow{4}{*}{$\begin{array}{l}\text { Offered gross } \\
\text { salary after } \\
\text { three years }\end{array}$} & \multirow{2}{*}{ Firms } & $n_{i}$ & 1 & 14 & 50 & 52 & 29 & 3 \\
\hline & & $f_{i}$ & 0.01 & 0.09 & 0.34 & 0.35 & 0.19 & 0.02 \\
\hline & \multirow{2}{*}{ Organisations } & $n_{i}$ & 16 & 85 & 31 & 3 & 0 & 0 \\
\hline & & $f_{i}$. & 0.12 & 0.63 & 0.23 & 0.02 & 0 & 0 \\
\hline
\end{tabular}

Note: $n_{i}$ means absolute frequency; $f_{i}$ means relative frequency; firms - potentional employers 
In order to find out whether these differences are statistically significant, we tested the homogeneity of both groups. The p-values of the gross starting salary, the salary after one year and the salary after three years reached the following values: $2.82263^{*} 10^{-18}$, $2.2293^{*} 10^{-24}, 4.07466^{*} 10^{-30}$.

All the stated p-values are smaller than the common levels of significance and that is why we can confirm that the division of salary categories differ in both groups of employers. The level of the offered salary is influenced by the fact, as to whether they employ graduates of economics or graduates of social work study programmes.

The results present an answer to our third research question. We found out that there are significant differences in the gross starting salary, which firms and organisations offer. The type of employer is another important factor.

We were further interested in the frequency of these changes in salaries offered by organisations and firms. In a similar fashion as with students, we considered three types of growth of the level of salaries and marked them $A, B$, and $C$. The results are shown in figure 2 .
From figure 2, we can see that organisations are more reluctant to increase the graduates' salaries in the course of the first three years than firms. Whereas more than $30 \%$ of organisations do not offer any increase in the course of the first three years from the beginning of employment (marked C), in the case of firms just 5\% are without any advancement in salaries. We can further see from figure 2 that organisations do not offer any advancement in salaries even after one year from the beginning of employment, and after another two years they do not offer any increase by more than one observed category. With firms, the situation is different. It is obvious from graph 2 that some units (exactly $4 \%$ ) of firms offer an increase in salaries by two or more observed categories already during the first year of employment. For confirmation of this difference with employers from the profit and non-profit spheres, we tested whether these differences are statistically significant. We used the homogeneity test. The $p$-values in the case of changes between gross starting salary, the salary after one year and the salary after three years are as follows: $1.08934^{*} 10^{-5}$, $5.74624^{*} 10^{-8}, 2.16757^{*} 10^{-14}$.

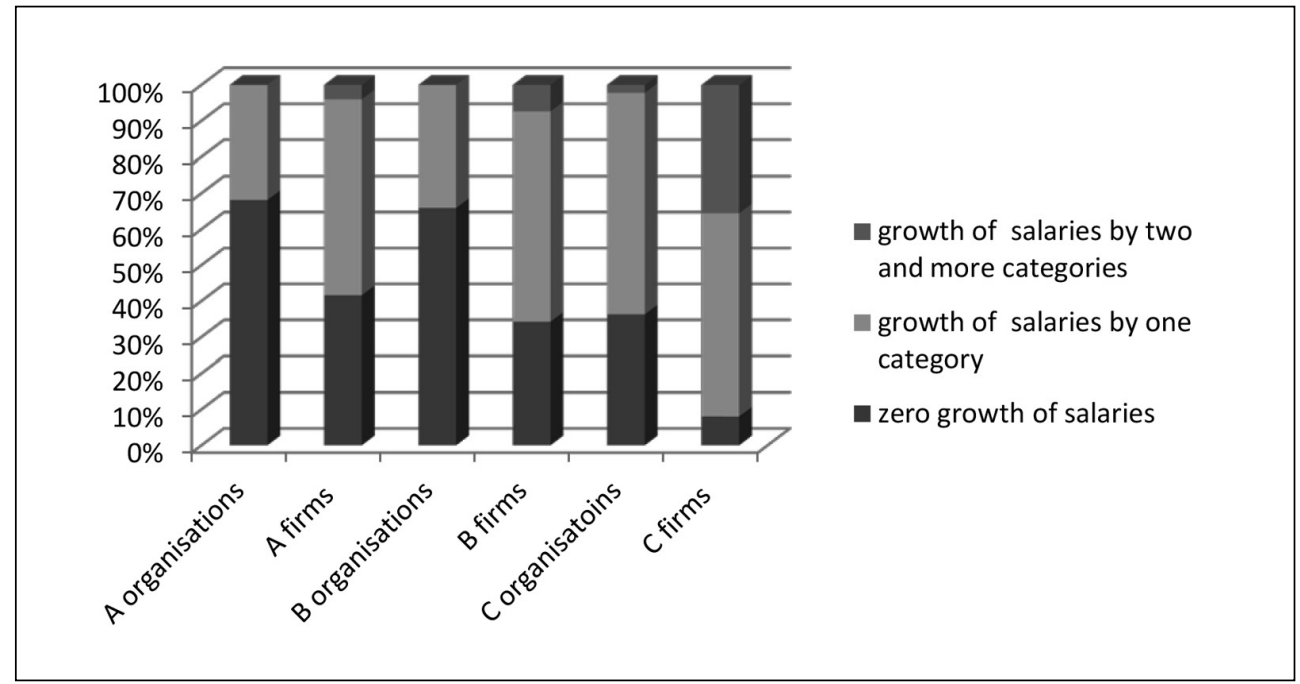

Note: firms - potentional employers of economics students (profit sector); 
All p-values are smaller than the common levels of significance. The test proved that the advancement in graduates' salaries in all observed periods (during the first year of employment, during the following two years and during the first three years from the beginning of employment) in organisations and firms differ.

Lastly we stated values presented in table 4 and grouped them in an association table the same way as with students, we created two wage categories: the gross salary of up to 19,999 CZK and the gross salary of 20,000 CZK and higher. So we added up the values of the first two wage categories and the values in the remaining columns. Firstly, we calculated odds, thus the ratios $=$ higher gross salary: lower gross salary for both observed types of employers. Thus we can claim that the odds for economics graduates to get a salary at a higher category are 60:89 in firms, whereas in organisations these odds for graduates are $5: 130$. Subsequently, we calculate the odds ratio. Thus we find out which employers are more advantageous and we can quantify this advantage. These odds ratios for gross salaries offered by firms and organisation are presented in table 5 .

\section{Tab. 5: Odds of employees for higher offered salaries}

\begin{tabular}{|c|c|c|c|c|c|}
\hline \multirow[b]{2}{*}{ Question } & \multicolumn{3}{|c|}{ Odds for higher offered salaries } & \multicolumn{2}{|c|}{ Interval of reliability } \\
\hline & & Odds & Odds ratio & $2.50 \%$ & $97.50 \%$ \\
\hline \multirow{2}{*}{ Offered gross starting salary } & Firms & 0.67 & \multirow{2}{*}{17.6} & \multirow{2}{*}{7.4} & \multirow{2}{*}{51.7} \\
\hline & Organisations & 0.04 & & & \\
\hline \multirow{2}{*}{ Offered gross salary after one year } & Firms & 2.31 & \multirow{2}{*}{21.7} & \multirow{2}{*}{11.44} & \multirow{2}{*}{44.06} \\
\hline & Organisations & 0.11 & & & \\
\hline \multirow{2}{*}{$\begin{array}{l}\text { Offered gross salary after three } \\
\text { years }\end{array}$} & Firms & 8.93 & \multirow{2}{*}{26.54} & \multirow{2}{*}{14.08} & \multirow{2}{*}{53.03} \\
\hline & Organisations & 0.34 & & & \\
\hline
\end{tabular}

Note: firms - potentional employers of economics students (profit sector);

Source: own organisations - potentional employers of social work students (non-profit sector).

The graduates from the economic branches have with their employers approximately 17.6 times higher odds for attaining a higher starting salary than those graduates from the social work study programmes with their employers. We can further see from the table that firms offer their employees after one year of employment a 21.7 times higher odds for a salary of over 20,000 CZK than organisations. And in the case of the salary offered after three years of employment, these odds are even 26.54 times higher.

From table 5 we can see that in all three observed gross salary categories, the value 1 is outside the $95 \%$ interval of reliability and that is why the stated odds ratios are statistically significant.

Our following research question, where we supposed that firms would offer not only a higher starting salary, but also faster advancements than organisations, is thus confirmed.

\subsection{Students versus Employers}

In the final part, we were interested in the finding to what extent the expectations of students and offers by employers differ in the case of gross starting salary, the gross salary after one year and after three years of employment. We will concentrate firstly on the students of economics (of both bachelor and master levels) and their employers. From tables 1 and 6 we can see that in all three categories, the modal category is the same for both groups.

In a similar fashion, as in the preceeding cases, we were examining whether the salary categories are for both observed groups, i.e. for employers and students, frequented in the same way. We used the homogeneity test. 
The results of $p$-values for the gross starting salary, the salary after one year and the salary after three years are as follows: 0.015844836 , 0.004647 , and $1.91156^{*} 10^{-5}$.

In the case of the starting salary, we reject homogeneity at the level of $5 \%$ of significance, but at the level of $1 \%$ of significance the homogeneity cannot be rejected. The situation is not unequivocal. In the case of the salary after one year and after three years of employment, the homogeneity of samples of students and employers can be rejected at common levels of significance.

Now let us concentrate on those students from social work and their employers. We want to ascertain whether the expectations of graduates and the reality salaries offered by employers differ. In the same way as in the previous cases, we used the homogeneity test. The resulting $p$-values are: $1.72065^{\star} 10^{-6}$, $3.62463^{*} 10^{-11}, 4.48857^{*} 10^{-14}$.

All $p$-values are significantly lower than the common levels of significance. The test proved that the division of salary categories between students and their employers differ.

We further compared the view at the salary growth in students and their employers. In a similar fashion as in previous cases, we marked the three types of the salary growth by A, B, and C and pictured them in the following figure 3 .

In the case of expected changes in salaries within the first year of employment (A), we can see from the graph that in both cases the opinions of students and employers do not differ very much. Employers are a little more reluctant to increase the salaries than the students of both groups expect. The greatest differences are to be found in the situation marked $C$, the changes throughout the whole three year period from the beginning of employment. Within the group of students of economics, there is not any single student who does not expect any advancement. But a certain small percentage of the firms questioned admit such a situation. Among the students from social programmes, their expectations for the increase in the level of salaries are for the first three year period significantly more optimistic than those on the part of their employers.

We further tested the homogeneity of the samples of students and their employers. The results of the test are shown in the following table 6.

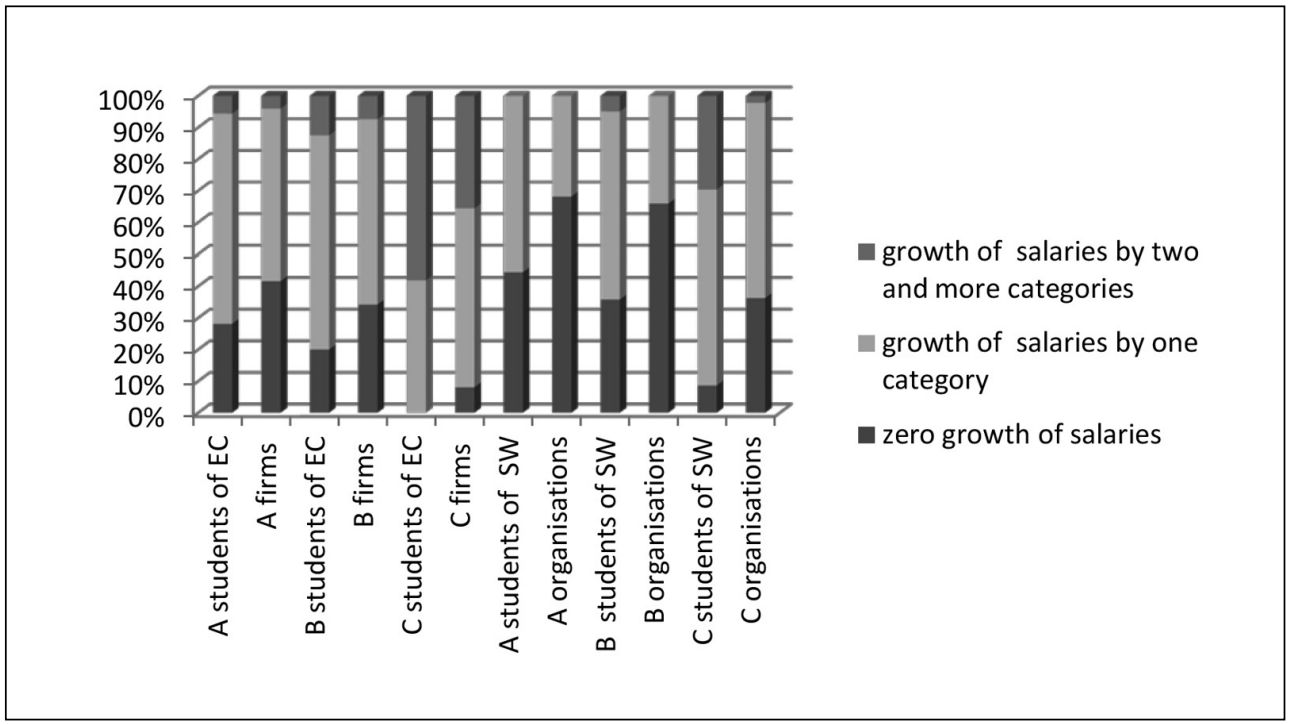

Note: firms - potentional employers of economics students (profit sector); 
Tab. 6: Results of the homogeneity test among students and employers

\begin{tabular}{l|c|c} 
& $\begin{array}{c}\text { p-value } \\
\text { (social work) }\end{array}$ & $\begin{array}{c}\text { p-value } \\
\text { (economics) }\end{array}$ \\
\hline $\begin{array}{l}\text { Change between the gross starting salary and the salary after } \\
\text { one year }\end{array}$ & 0.0005981 & 0.0475512 \\
\hline $\begin{array}{l}\text { Change between the gross salary after one year and the } \\
\text { gross salary after three years }\end{array}$ & $1.66882^{*} 10^{-5}$ & 0.0022851 \\
\hline $\begin{array}{l}\text { Change between the gross starting salary and the gross } \\
\text { salary after three years }\end{array}$ & $1.41598^{*} 10^{-10}$ & $2.07895^{\star} 10^{-7}$ \\
\hline
\end{tabular}

Source: own

The first column with $p$-values is related to the students from social work and their employers, i.e. organisation. The second column with $p$-values presents results of the homogeneity test of the samples of students from the economic branches and their employers, i.e. firms. We will devote our attention firstly to the students from economics and their employers from the point of view of their expectations for the salary increase in the first year of their employment. The $p$-value is, in this case, very close to the $5 \%$ level of significance. That is why we are justified in claiming that in this case we did not succeed in determining the difference with regard to the expectations for the salary increase throughout the first year of employment. All other presented p-values are significantly lower than the 5\% level. That is why we can claim that at this level of significance we have demonstrated differences in expectations on the part of students and their employers with regard to the salary advancements during the first three years of their employment. And by means of the look at the empirical data we can see that students are in all cases more optimistic than their employers. The expectations of students are higher than their employers offer.

The last research questions were related to the direct confrontation between the real offer by employers and the students' expectations. We supposed that the students from both study programmes will be more optimistic, i.e. the expectations for both the starting salary and salary advancements will be higher than their employers' offer. Concerning the starting salary, it is ambiguous in the case of economics students and we cannot claim that their expectations are in the area of the starting salary significantly statistically different from their employers' offer. In contrast to this, the expectations on the part of students from social work are statistically different from their employers' offer. Concerning the salary advancements, the situation is for both groups the same. Both future economists and social workers have higher expectations than the real employers' offer is.

\section{Discussion}

In the framework of our study, we dealt with salary expectations on the part of tertiary school students and their direct confrontation to the offer by their potential employers. The main factors, which we considered, were the level of tertiary education (bachelor versus master level) and the field of study. We intentionally have chosen two different study programmes, economics and social work. It is however obvious that there are a number of other factors, which may influence students' expectations.

One of the main factors could be gender. There have been many studies proving that there are certain gender differences. For example the comparison of salaries in the USA, Canada and Great Britain showed that women in biological sciences earn less than men. Also certain differences in the level of salaries on the part of different racial and ethnic groups were noticed (AIBS Salary Survey Results Available, 2002; Salary Expectations, 2004).

There are a number of studies, which deal with gender differences. For example in Ireland, an extensive study was carried out, where significant differences in the expected salary were found in both short-term and longterm horizons. Women expect in both cases significantly lower salaries than men (Delaney, 
Harmon, \& Remond, 2010). On the contrary in the USA, an interesting finding has been published, which reveals that women and men expect similar starting salaries, but women anticipate significantly lower incomes within the following years, even assuming they are continuously employed after finishing schools (Blau \& Ferber, 1991). Another American study nevertheless stresses the salary differences (Heide, 2012). The Australian labour market also reveals salary differences ( $\mathrm{Li} \&$ Miller, 2012). A Dutch study pointed out the fact that in the course of time there appear many favourable changes with respect to the benefit of women, even though women still earn less than men (Fransen, Platenga, \& Vlasblom, 2012).

An important study in Slovenia, which has dealt with gender differences not only in salaries, but also concerning entrepreneurship, comes to the conclusion that differences could arise according to the type of profession, which is for a certain gender specific, and presents also the fact that women have a lower tendency to go into business than men (Tominc \& Rebernik, 2003). Even in the case of self-employed people, there are significant differences between the earnings of men and women (Hundley, 2001). Another study on the basis of data from Great Britain points out the fact that lower incomes in women appear especially when women take care of children (Dolton \& Makepeace, 1987). It is thus evident that the factor of gender is one of the important variables, which may influence salary expectations. One of our research samples (students of social work) was created predominantly by women. This was given by the fact that this study programme is selected almost exclusively by women. So we were not able to carry out gender comparison within the framework of our research, even if this would be very interesting.

Besides gender, there are many other variables, which may be relevant to the level of salary, which we did not touch in our research. International studies, which examine the influence of body weight on the level of the salary, are extremely interesting (Brunello \& D'Hombres, 2007). In several European countries (Portugal, Spain, Austria, Denmark, Belgium, Ireland and Finland) the researchers found out that an increase in body mass index by $10 \%$ causes a decrease in the level of income for men by $3.27 \%$ and $1.86 \%$ for women. Another study examining the relation between BMI and household incomes speaks more to the detriment of women (Villar \& Guintana-Domenque, 2009).

There are many factors, which may influence the salary. In Germany another study was carried out, which examined whether the body height could also influence the salary level (Heineck, 2005). It is but not completely clear, whether the physique does not primarily have influence on the work performance and only as a secondary factor on the salary level.

A number of other factors have already been mentioned in the introductory part of our article - a significant role is played by the social context, the level of the parents' education and parents' incomes. In addition to this, some personal characteristics of an individual may also play an important role. More ambitious students have higher aspirations, aim at higher working positions and value their mathematical abilities, and have higher salary expectations than those who fear their failure to find a job (Khosrozadeh et al., 2013).

It is however clear that in the framework of one study it is not possible to analyze all variables which may influence the results. But it shows that not all factors have been thoroughly examined in this area and there is a space for further research.

\section{Conclusions}

In our research, we examined the expectations of university students from two different study programmes: economics and social work, and the reality of wage policy of their potential employers. We asked the students questions about the expected gross starting salary, gross salary after one year of employment and after three years of employment. The same questions were posed also to potential employers for the above mentioned graduates. The gross salary was divided into six categories. And we compared as to what extent the expectations of students differ from the real offer by employers. By means of the homogeneity test, the differences in the division of both types of students sammples were ascertained (i.e. students of economics and social work) and their potential employers (i.e. firms and organisations) in all three questions. Only in the case of starting salaries, the expectations of the economics students and their employers 
differ at the level of $5 \%$ of significance (not at the level of $1 \%$ ).

When comparing the expectations and reality of the salary level of advancement during the first three years of employment, the students from economics were more optimistic than those from social work. It was demonstrated that firms offer their employees a faster salary increase than organisations. We further proved that the students from social work have their expectations for a higher salary at a level higher than organisations offer. The students from economics had a more realistic look at the salary increase in the case of the first year of employment. The difference between their expectations and the reality offered by firms was not demonstrable at lower levels of significance. But in the case of salary increase throughout the whole period of three years from the beginning of employment, even those students appear to be more optimistic.

When we calculated the odds ratio, we managed to find a $95 \%$ interval of reliability for these odds by means of a logarithmic-linear model. With regard to the question asking about the level of the starting salary and the salary after one year, it was not demonstrated that the students of economics and firms estimate their odds for salaries of a higher category differently. In all other cases the difference was proved and quantified.

Generally speaking, the students from economics are more optimistic and at the same time more realistic than those from social work. Those students from social work have less realistic expectations both with regard to the question of the salary increase and in its level after three years of employment.

Firms are towards the graduates starting their employment more generous in the course of the first three years, with respect to both the level of salaries and salary increase, than are the organisations, the employers of social work graduates.

As we have shown in the introduction, studies were published, which claim that students have realistic expectations concerning their future salaries (Dominitz \& Manski, 1996; Webbink \& Hartog, 2004 and others). Some authors though suggest that the expectations on the part of students are overevaluated by approximately $15 \%$ (Jerrim, 2011). The results of research Graduate Barometre state that Czech students expect the salary of about
$30,000 \mathrm{CZK}$, i.e. 1,100 $€$. (Czech graduates "modest" regarding starting salaries, survey, 2014). Our investigation revealed that a salary like this is really offered by less than $20 \%$ of firms, which employ the economics graduates and primarily after three years from the beginning of employment. Organisations, which employ social work graduates, will not offer such a salary even after three years. It is thus obvious that the study field has a great impact on the level of the future salary and that the students adjust their expectations during the course of their studies. The expectations on the part of students from social work are lower than those of their counterparts studying economics and in spite of that, with regard to the offer by their potential employers, still less realistic.

\section{References}

AIBSSalarySurveyResultsAvailable.(2002). BioScience, 52(12), 1149. doi:10.1641/00063568(2002)052[1149:AN]2.0.CO;2.

Betts, J.R. (1996). What do students know about wages? Evidence from a survey of undergraduates. Journal of Human Resources, 31(1), 27-56. doi:10.2307/146042.

Blau, F.D., \& Ferber, M.A. (1991). Career Plans and Expectations of Young Women and Men. Journal Of Human Resources, 26(4), 581607. doi:10.2307/145976.

Botelho, A., \& Pinto, L.C. (2004). Students' expectations of the economic returns to college education: results of a controlled experiment. Economics of Education Review, 23(6), 645653. doi:10.1016/j.econedurev.2004.03.005.

Brunello, G., Lucifora C., \& Winter-Ebmer, R. (2004). The Wage Expectations of European Business and Economics Students. Journal of Human Resources, 39(4), 1116-1142. doi: $10.2307 / 3559041$.

Brunello, G., \& D'Hombres, B. (2007). Does body weight affect wages?: Evidence from Europe. Economics\&Human Biology, 5(1), 1-19.

Carvajal, M.J., Benada, D., Bozorgmanesh, A., Castillo, M.A., Pourmasiha, K., Rao, P., et al. (2000). Inter-gender Differentials between College Students' Earnings Expectations and the Experience of Recent Graduates. Economics of Education Review. 19(3), 229243. doi:10.1016/S0272-7757(99)00034-5.

Ettedge, M.L., \&. Nunamaker, T.R. (1993). Starting Salaries of Four-Year Accounting Graduates, 1961-1991. Issues in Accounting Education. 8(2), 248-259. 
Czech graduates among "modest" regarding starting salaries, survey. (2014). Regional Today, 1-2, Business Source Complete.

Delaney, L., Harmon, C., \& Redmond, C. (2011). Parental education, grade attainment and earnings expectations among university students. Economics Of Education Review, 30(6), 1136-1152. doi:10.1016/j. econedurev.2011.04.004.

Delaney, L., Harmon, C., \& Redmond, C. (2010). Decomposing Gender Differences in College Student Earnings Expectations (UCD Geary Institute Discussion Paper Series). Dublin: UCD. Retrieved May 24, 2015, from http://www.ucd.ie/geary/static/publications/ workingpapers/gearywp201038.pdf.

Deloitte. (2011). First steps into the labour market. International survey of students and graduates. Retrieved August 5, 2015, from http://www.vu.It/site_files/InfS/Naujienos/First_ steps_into_the_labour_market.pdf.

Dolton, P., \& Makepeace, G. (1987). Marital status, childrearing and earning differentials in the graduate labour market. Economic Journal, 97(388), 897-922. doi:10.2307/2233079.

Dominitz, J., \& Manski, C.F. (1996). Eliciting Student Expectations of the Returns to Schooling. Journal Of Human Resources, 31(1), 1-26. doi:10.2307/146041.

Fransen, E., Plantenga, J., \& Vlasblom, J.D. (2012). Why Do Women Still Earn Less Than Men? Decomposing the Dutch Gender Pay Gap, 1996-2006. Applied Economics, 44(33), 43434354. doi:10.1080/00036846.2011.589818.

Hartog, J., Ding, X., \& Liao, J. (2014). Is Earnings Uncertainty Relevant for Educational Choice? An Empirical Analysis for China. Education Economics, 22(5), 471-483. doi: 10.1080/09645292.2012.688580.

Heckert, T.M., \& Wallis, H.A. (1998). Career and salary expectations of college freshmen and seniors: Are seniors more realistic than freshmen? College Student Journal, 32(3), 334.

Heide, B. (2012). Experts: Woman can help themselves overcome pay gap: Cracking the pink ceiling. Journal Record.

Heineck, G. (2005). Up in the Skies? The Relationship between Body Height and Earnings in Germany. Labour, 19(3), 469-489. doi:10.1111/j.1467-9914.2005.00302.x.

Hundley, G. (2001). Why Women Earn Less Than Men in Self-Employment. Journal Of Labor Research, 22(4), 817-829. doi:10.1007/ s12122-001-1054-3.
Jerrim, J. (2011). Do UK Higher Education Students Over estimate Their Starting Salary? Fiscal Studies, 32(4), 483-509. doi:10.1111/ j.1475-5890.2011.00148.x.

Khosrozadeh, N., McGinnis, J., Schnusenberg, O., \& Jones, L.C. (2013). Identifying Differences in Business Students' Salary Expectations. Journal Of Education For Business, 88(1), 16-25. doi:10.1080/08832323 .2011 .630433 .

Li, I.W., \& Miller, P.W. (2012). Gender Discrimination in the Australian Graduate Labour Market. Australian Journal Of Labour Economics, 15(3), 167-199.

Maddocks, H., \& Poole, B. (2009). Starting Salary Expectations Of College Students. Proceedings For The Northeast Region Decision Sciences Institute (NEDSI), 263-266.

Maršíková, K., \& Anchor, J.R. (2006). Student Perceptions of the Returns to Higher Education in the Czech Republic and the United Kingdom: Evidence from Economics and Business Studies. E\&M Ekonomie a Management, 9(2), 33-42.

Menon, M.E. (1997). Perceived rates of return to higher education in Cyprus. Economics of Education Review, 16(4), 425430. doi:10.1016/S0272-7757(96)00065-9.

Salary Expectations. (2004). Black Collegian, 35(1), 70. Retrieved August 5, 2015, from http://connection.ebscohost.com/c/ articles/15109257/salary-expectations.

Tominc, P., \& Rebernik, M. (2003). Some characteristics of the gender differences in economy in Slovenia. In Enterprise In Transition: International Conference Proceedings (pp. 9951005).

Villar, J.G., \& Quintana-Domenque, C. (2009). Income and body mass index in Europe. Economics \& Human Biology, 7(1), 7383. doi:10.1016/j.ehb.2009.01.006.

Walker, I., \& Yu, Z. (2011). Differences by Degree: Evidence of the Net Financial Rates of Return to Undergraduate Study for England and Wales. Economics of Education Review, 30(6), 1177-1186. doi:10.1016/j. econedurev.2011.01.002.

Webbink, D., \& Hartog, J. (2004). Can Students Predict Starting Salaries? Yes!. Economics of Education Review, 23(2), 103113. doi:10.1016/S0272-7757(03)00080-3.

Wolter, S.C. (2000). Wage Expectations: A Comparison of Swiss and US Students. Kyklos, 53(1), 51-69. doi:10.1111/1467-6435.00109. 


\section{Economics}

RNDr. Jana Šimsová, Ph.D. Jan Evangelista Purkyně University in Ústí nad Labem Faculty of Social and Economic Studies Department of Mathematics and Informatics jana.simsova@ujep.cz
PhDr. Alice Reissová, Ph.D. Jan Evangelista Purkyně University in Ústí nad Labem

Faculty of Social and Economic Studies Department of Management alice.reissova@ujep.cz 


\section{Abstract}

\section{HOW MUCH WILL I EARN? EXPECTATIONS VERSUS REALITY}

\section{Jana Šimsová, Alice Reissová}

When choosing a career, the issue of the following employment on the labour market and related level of the salary plays an important role. There are many studies which deal with the findings with respect to students' expectations. The benefit of our work is that we compare these expectations to the real offer by potential employers. In the framework of our research, we have chosen two different fields of studies, on the one hand the students of economics, who find their employment in the entrepreneurial sphere, the second group was composed of students from social work, who target their careers at the area of social services and their employers will be predominantly nonprofit organisations. We took a look as to whether there are differences between the expectations and the reality concerning both the starting salary and its increase during the first three years of employment and thereby grouped into two sections (profit and non-profit). Our conclusions reveal that the level of the salary depends on the field studied. The levels of the salary offered in the profit and non-profit sectors significantly differ. A significant difference is also obvious in the possible salary advancements in the course of the first three years of employment. The students of economics are more likely to estimate the level of their starting salary, but they count on faster advancements. On the other hand, potential employers of economics graduates do not offer such an increase. In the area of social work, i.e. in the non-profit sector, the difference between the students' expectations and the offers by their potential employers is even greater. The students from social work see their odds for higher salaries and their advancements more optimistically, than their potential employers are prepared to offer.

Key Words: Expected salary, gross salary, salary advancement, university graduates, economics, social work, homogeneity test, odds ratio, logarithmic - linear models.

JEL Classification: M5, I2, J23.

DOI: 10.15240/tul/001/2016-2-001 